\title{
ANALISIS MOTIVASI, LINGKUNGAN KERJA DAN KINERJA KARYAWAN : STUDI PADA PT. BARRIX SININDO JAKARTA
}

\author{
Muhammad Putra Aviantara \\ Universitas Pendidikan Indonesia \\ muhammad.putra@student.upi.edu \\ Sumiyati \\ Universitas Pendidikan Indonesia \\ sumiyati@upi.edu \\ Masharyono \\ UniversitasPendidikan Indonesia \\ masharyono@upi.edu
}

\begin{abstract}
Tujuan-Tujuan penelitian ini adalah untuk mengetahui gambaran motivasi, lingkungan kerja dan kinerja karyawan

Desain/metodologi/pendekatan- Desain penelitian ini adalah cross sectional. Penelitian ini menggunakan pendekatan deskriptif dengan metode explanatory survei. Unit analisis karyawan sebanyak 30 orang. Pengumpulan data dengan menggunakan kuisioner. Teknik analisis yang digunakan adalah teknik deskriptif dengan menggunakan distribusi frekuensi

Temuan - Berdasarkan hasil penelitian, didapatkan hasil bahwa motivasi dalam kategori tinggi dengan perolehan skor 48,2\%, lingkungan kerja dalam kategori kondusif dengan perolehan skor 39,8\% dan kinerja berada pada kategori tinggi dengan perolehan skor $49,4 \%$.

Orisinalitas/nilai- Penelitian ini memberikan dasar untuk memahami isu-isu motivasi dan lingkungan kerja terhadap kinerja karyawan. Perbedaan penelitian ini dengan penelitian sebelumnya adalah terletak pada objek yang merupakan perusahaan jasa ekspedisi expor dan impor yaitu PT. Barrix Sinindo Jakarta, dengan variabel yang diteliti yaitu motivasi, lingkungan kerja dan kinerja karyawan, serta menggunakan teori atau referensi yang berbeda dengan peneliti sebelumnya.
\end{abstract}

Kata Kunci :, motivasi, lingkungan kerja, motivasi

Jenis Artikel : Studi Kasus

\begin{abstract}
Purpose - This research is conducted to know the description of motivation, work environment and employee performance of PT. Barrix Sinindo Jakarta.

Design / methodology / approach - Unit of analysis in this study ie employees of PT. Barrix Sinindo Jakarta, totaling 30 people. Data collection techniques using questionnaires, While the data analysis techniques performed is descriptive and verifikatif analysis. The research method used is explanatory survey method.

Findings - Based on the results of the study, it was found that job motivation in the high category to the score of 48,2\%, work environment in the conducive category with the score of 39,8\% and performance of employee was in the high category with the score of $49,4 \%$

Originality/value - This study provides a basis for understanding the issues of motivation and work environment on performance of empliyee. The difference of this research with previous research is located on the object which is the company in expedition that is in PT. Barriq Sinindo Jakarta, with the variables studied motivation, work environment and performance of employee, and using theory or reference different from researcher previous.
\end{abstract}

Keywords: Motivation, work environment and performance of employee Article Type : Case Study 


\section{PENDAHULUAN}

Perkembangan bisnis yang semakin pesat dan tingkat persaingan yang semakin tajam membuat perusahaan harus meningkatkan dan mengembangkan kinerjanya disemua bidang. Setiap perusahaan memiliki cara agar perusahaannya dapat bertahan ditengah-tengah persaingan yang ketat, salah satunya bidang yang harus di tingkatkan ialah sumber daya manusia. Ini dilakukan agar perusahaan tetap bertahan dalam persaingan global.

Salah satu industri yang kini sedang berkembang adalah industri dibidang jasa ekspedisi. Fenomena perkembangan industri jasa pengiriman barang yang semakin pesat dewasa ini karena permintaan konsumen yang semakin meningkat dalam jasa pengiriman barang menimbulkan bertambahnya perusahaan yang memasuki pasar jasa untuk dapat bersaing dan bertahan. Menghadapi kenyataan banyaknya jasa pengiriman barang yang sejenis dengan kualitas yang beragam dan selera konsumen yang mudah berganti serta munculnya pesaing-pesaing baru, dampaknya adalah semakin banyak perusahaan jasa pengiriman barang yang ditawarkan dalam bentuk pelayanan yang beragam. Kondisi demikian membuat pelanggan dihadapkan kepada berbagai alternatif pilihan pembelian dalam rangka memenuhi kebutuhannya, sementara dipihak perusahaan menimbulkan iklim persaingan yang semakin tinggi dalam mendapatkan konsumen/pelanggan.

Menurut Purwanti (2008), dalam bisnis ekspedisi sebagian besar sudah dikenal namanama seperti TIKI, ESL, JNE serta perusahaan yang sudah lama sekali mengurusi jasa pengiriman mulai surat sampai dengan paket barang yang merupakan satu-satunya perusahaan BUMN yaitu Pos Indonesia. Selain itu, terdapat nama-nama perusahaan besar berskala global (Internasional), seperti DHL Express, UPS, TNT Express International, FedEx dan lain-lain. Banyaknya perusahaan yang bergerak di jasa ekspedisi menyebabkan persaingan bisnis di pasar jasa kiriman barang dan paket dokumen ini juga ketat. Perusahaan tersebut berusaha untuk memberikan layanan yang terbaik untuk menarik konsumen yang sebanyak-banyaknya. Selain menjanjikan pelayanan terbaik, mereka juga berupaya menghadirkan berbagai produk inovatif jasa layanan pengiriman barang maupun paket dokumen. Sebagai sebuah peluang usaha, jasa pengiriman barang ini prospeknya juga masih sangat menjanjikan. Terlebih dengan adanya trend dikalangan perusahaan-perusahaan besar yang belakangan ini cenderung menyerahkan kepada pihak lain untuk urusan pengiriman barang hingga penanganan gudang kepada perusahaan logistik.
Permasalahan kinerja karyawan dalam sebuah perusahaan menjadi masalah penting dalam Manajemen Sumber Daya Manusia. Tenaga kerja perlu dipacu kinerjanya, mengingat sumber daya manusialah yang mengatur atau mengelola sumber daya yang lainnya. Perhatian dibidang sumber daya manusia tidak boleh diabaikan hal itu merupakan aspek penting untuk merencanakan karyawan agar bekerja lebih efektif dan terus ditingkatkan dalam rangka mencapai tujuan perusahaan (Senen, Masharyono, Triananda, \& Sumiyati, 2016). Kinerja karyawan sangat penting dalam pencapaian kinerja karyawan yang baik, maka perlu diupayakan faktor-faktor yang baik untuk mendukung tenaga kerja agar dapat bekerja secara optimal (Latib, dll. 2016).

Karyawan merupakan salah satu faktor terpenting dalam suatu perusahaan ekpedisi, tanpa adanya karyawan sangatlah sulit untuk mencapai tujuan perusahaan. Karyawanlah yang menentukan maju atau mundurnya perusahaan ini dan menentukan keberhasilan perusahaan ekspedisi di masa yang akan datang, dengan memiliki tenaga-tenaga kerja yang terampil dengan kinerja yang tinggi, maka perusahaan telah mempunyai aset yang sangat mahal, yang sulit dinilai dengan uang. Untuk mendapatkan karyawan seperti yang diharapkan, perusahaan ekspedisi harus memiliki kinerja karyawan yang bagus, agar dapat bekerja dengan baik dan dapat meningkatkan profit perusahaan. Sumber daya manusia berperan dalam mencapai tujuan organisasi dan sumber daya manusia juga merupakan faktor dinamis yang mampu menentukan maju atau mundurnya suatu organisasi (Masharyono \& Sumiyati:2016).

Masalah kinerja ini banyak dialami oleh perusahaan-perusahaan ekspedisi. Salah satu perusahaan ekspedisi yang mengalami masalah kinerja adalah PT. Cahya Pinastika Jaya. Masalah Trunover intention, keluar masuknya karyawan di PT. Cahya Pinastika Jaya menyebabkan penurunan kinerja setiap tahunnya. Menyebabkan tergangungnya kegiatan perusahaan (Gilang,2015). Masalah yang sama juga dihadapi oleh PT. Pelopor Pratama Lancar Pribadi, banyaknya karyawan yang datang terlambat, tata letak ruangan kerja dan lokasi yang dinilai tidak kondusif menggangu kinerja karyawan. Kinerja karyawan yang menurun ini terlihat dari target perusahaan yang tidak tercapai, hal ini jelas merugikan perusahaan (Akbar,2016).

Masalah serupa dialami oleh PT. Barrix Sinindo. Perusahaaan ekspedisi PT. Barrix Sinindo Jakarta ini sudah bergerak cukup lama sejak tahun 2010, berlokasi di Jatiwaringin, Jakarta Timur. . Perusahaan ini bergerak di dalam bidang jasa, melayani perusahaan. Pengiriman 
barang yang biasa di lakukan PT. Barrix Sinindo meliputi pengiriman Eksport dan Import ke berbagai macam daerah dan wilayah di dalam maupun luar negeri. PT. Barrix Sinindo didirikan oleh Bapak Robby.

Keberhasilan suatu perusahaan sangat dipengaruhi oleh kinerja karyawannya, oleh karena itu setiap perusahaan akan selalu berusaha untuk meningkatkan kinerja karyawan agar tujuan perusahaan dapat tercapat secara maksimal. Salah satu kunci keberhasilan suatu perusahaan adalah bagaimana membuat karyawan memiliki kemampuan dalam bidangnya dan menimbulkan rasa motivasi yang tinggi sehingga dapat meningkatkan kinerja pada karyawannya. Kinerja di kaitkan dengan konsep kemampuan karena untuk perbaikan dalam meningkatkan kualitas yang terbaik. Kemampuan tersebut merupakan kapasitas seseorang didalam mengerjakan berbagai macam tugas dalam pekerjaannya (Willey, 2011).

Pendekatan yang digunakan dalam penelitian ini adalah perilaku organisasi. Hessel (2007:178) menyatakan faktor-faktor yang mempengaruhi kinerja organisasi adalah motivasi, budaya perusahaan, kompensasi, kepemimpinan, kepuasan kerja, disiplin kerja, lingkungan kerja dan komitmen organisasi. Kinerja pegawai dipengaruhi oleh berbagai faktor Gibson et al, (1995:375), antara lain: a) Faktor individu, yaitu kemampuan dan keterampilan (mental dan fisik), latar belakang (pengalaman, keluarga, dst), dan demografis (umur, asalusul, dll), b) Faktor organisasi, adalah sumber daya, kepemimpinan, imbalan (kompensasi), struktur organisasi, dan diskripsi pekerjaan (job description), c) Faktor psikologis, ialah persepsi, sikap, kepribadian, pola belajar, dan motivasi. Hal ini juga diperkuat oleh penelitian Resiona (2014) menunjukkan bahwa terdapat pengaruh secara simultan antara penempatan pegawai, lingkungan kerja fisik dan motivasi kerja terhadap kinerja pegawai di kantor Bappeda Kabupaten Flores Timur.

Penelitian terdahulu yang dilakukan oleh Afsheen Fatima, Arshad Zaheer, Imran Yousaf dan Iram Batool (2012:1458) menyatakan bahwa, adanya hubungan yang positif dan signifikan antara lingkungan kerja dengan kinerja karyawan dalam suatu perusahaan. Lingkungan kerja merupakan faktor penting karena semua faktornya berhubungan dengan pekerjaan dan perusahaan yang mempengaruhi hubungan antara karyawan, pekerjaan dan perusahaan.

Tujuan penelitian ini adalah: memperoleh gambaran motivasi kerja karyawan PT. Barrix Sinindo, gambaran gambaran lingkungan kerja karyawan PT. Barrix Sinindo, gambaran kinerja karyawan PT. Barrix Sinindo, gambaran pengaruh motivasi terhadap kinerja karyawan PT. Barrix Sinindo.

\section{KAJIAN PUSTAKA}

Proses pembentukan perilaku tersebut dimulai dari setiap anggota organisasi yang dilakukan secara ilmiah, Perilaku organisasi adalah suatu bidang studi yang mempelajari dampak perorangan, kelompok, dan struktur pada perilaku dalam organisasi dengan maksud menerapkan pengetahuan tentang hal-hal tersebut demi perbaikan efektivitas organisasi (Robbins and Judge, 2013).

Robbins and Judge (2013) menyatakan bahwa kategori dalam perilaku organisasi terdiri dari individu, kelompok dan sistem organisasi yang terdapat dalam masing-masing bagian. Pada individu level dalam perilaku organisasi terdiri dari : 1) Diversity in Organization, 2) Attitude and Job Satisfaction, 3) Emotions and Moods, 4) Personality and Values, 5) Perception and Individual Decision Making dan 6) Motivation. Motivasi terdapat pada pada level individu. Motivasi adalah satu proses yang meghasilkan suatu intensitas, arah, dan ketekunan individual dalam usaha untuk mencapai tujuan (Robbins and Judge, 2013).

Sumber : Robbins and Judge (2013)

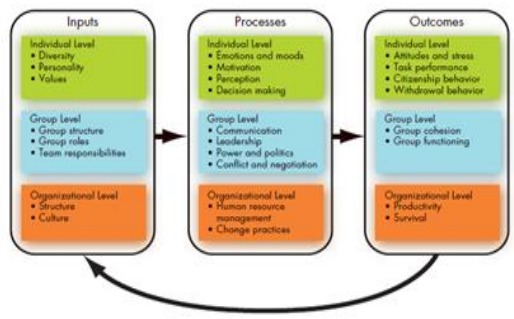

\section{GAMBAR 1}

\section{A BASIC ORGANIZATIONAL BEHAVIOR} MODEL

Beberapa individu didorong untuk menjadi orang yang berhasil, tetapi tidak semua orang bisa mendapatkan perlakuan yang sama karena motivasi individu berbeda-beda. Tingkat motivasi individu bervariasi dengan individu lainnya, motivasi sebagai proses yang menjelaskan intensitas, arah, dan ketekunan usaha individu untuk mencapai tujuan perusahaan (Robbins and Judge, 2013).

\section{Kajian Teori Motivasi}

Motivasi merupakan hal yang menyebabkan, menyalurkan dan mendukung perilaku manusia. Supaya mau bekerja giat dan antusias mencapai hasil yang memuaskan, motivasi semakin penting karena atasan membagikan pekerjaan kepada bawahannya untuk dikerjakan dengan baik dan teritegrasi kepada tujuan yang diinginkan. Seseorang yang termotivasi menunjukan usaha dan bekerja keras 
Robbins \& Coulter (2010). Purnama (2008) mengungkapkan motivasi adalah keseluruhan proses pemberian motivasi bekerja kepada bawahan sedemikian rupa sehingga mereka mau bekerja dengan ikhlas demi tercapainya tujuan organisasi dengan efisien dan ekonomis. Motivasi itu yang memberikan energi, mengarahkan, dan memelihara perilaku manusia. Dalam manajemen sumber daya manusia, keinginan seseorang untuk melakukan yang terbaik mungkin pekerjaan atau untuk mengerahkan upaya maksimal untuk melakukan tugas yang diberikan (Gomez-Mejia, R, \& Balkin, 2012)

Faktor-faktor yang mempengaruhi motivasi menurut (Senen, Hadi Syamsul dan Solihat, 2008) adalah prestasi kerja, pengharapan, sifat dan ruang lingkup, peningkatan, tantangan, tanggung jawab, administrasi dan manajemen, supervisi, hubungan ntar perseorangan, kondisi kerja, gaji, status, dan keamanan kerja.

Dimensi motivasi menurut David McClelland yaitu: 1) Need for Achievment (Kebutuhan dalam mencapai kesuksesan), 2) Need for Power (kebutuhan dalam kekuasaan aau otoritas kerja), dan 3) Need for Affiliation (kebutuhan untuk berafiliasi).

\section{Kajian Teori Lingkungan Kerja}

Kondisi lingkungan kerja dikatakan baik apabila manusia dapat melaksanakan kegiatan secara optimal, sehat, aman dan nyaman. Kesesuaian lingkungan kerja dapat dilihat akibatnya dalam jangka waktu yang lama. Lingkungan kerja yang kurang baik dapat menuntut tenaga kerja dan waktu yang lebih banyak dan tidak mendukung diperolehnya rancangan sistem kerja yang efisien.

menyatakan bahwa lingkungan kerja melibatkan semua aspek yang bertindak dan bereaksi pada tubuh dan pikiran seorang karyawan. Lingkungan kerja menurut adalah keseluruhan alat perkakas,,lingkungan di mana seseorang bekerja, metode kerja,,serta pengaturan kerja. (Senen, 2009) menyatakan bahwa lingkungan kerja fisik merupakan suatu keadaan yang berkaitan dengan tempat kerja secara nyata dapat diamati dan dirasakan, yaitu masalah kebisingan, pencahayaan, ventilasi, suhu, keamanan, waktu istirahat, kelembapan dan musik yang berhubungan erat dengan karakteristik pekerjaan.

menyatakan bahwa terbentuknya suatu kondisi kerja yang dapat menunjang kemampuan karyawan, diantaranya yaitu:

1. Lingkungan kerja fisik adalah semua keadaan berbentuk fisik yang terdapat disekitar tempat kerja, seperti penerangan, suhu, suara bising, jaminan keamanan, kebersihan dan penataan ruangan.

2. Lingkungan kerja non fisik adalah semua keadaan yang terjadi berkaitan dengan hubungan kerja, baik hubungan atasan dengan karyawan ataupun hubungan sesama rekan kerja.

\section{Kajian Teori Kinerja Karyawan}

Rivai \& Jauvani (2009:548)

menyatakan bahwa, kinerja merupakan suatu fungsi dari motivasi dan kemampuan. Burmbach dalam Amstrong (2010:248) mengemukakan bahwa kinerja dapat dinyatakan sebagai perilaku dan hasil. Robbins \& Coulter (2012) karena kinerja adalah hasil akhir yang diberikan oleh pegawai dalam mencapai tujuan dari sebuah organisasi apakah kinerja yang diberikan baik atau buruk.

PT. Barrix Sinindo menjelaskan bahwa terdapat 4 dimensi kinerja pegawai yang harus dimiliki karyawan, yaitu : PT. Barrix Sinindo menjelaskan bahwa terdapat 4 dimensi kinerja pegawai yang harus dimiliki karyawan, yaitu :

1. Kejujuran, yaitu ketulusan hati pegawai dalam melaksanakan dan kemampuan untuk tidak menyalahgunakan wewenang yang diembannya.

2. Kedisiplinan, yaitu kesadaran dan kesediaan seseorang menaati semua peraturan perusahaan dan norma-norma sosial yang berlaku.

3. Loyalitas (Kesetiaan), yaitu tekat dan kesanggupan untuk menaati, melaksanakan, dan mengamalkan sesuatu yang ditaati dengan penuh kesabaran dan tanggungjawab.

4. Kerjasama, yaitu kemampuan pegawai untuk bekerjasama dengan orang lain dalam melakukan tugasnya.

5. Perilaku/sikap, yaitu bentuk evaluasi atau reaks perasaan.

\section{METODE PENELITIAN}

Terdapat dua variabel yaitu variabel terikat dan variabel bebas. Variabel terikat adalah variabel yang menjadi perhatian 
utama bagi peneliti. Variabel bebas adalah salah satu yang mempengaruhi variabel terikat baik secara positif atau negatif (Sekaran \& Bougie, 2013:69).

Variabel bebas (independent variable) yang pertama pada penelitian ini adalah $\left(\mathrm{X}_{1}\right)$ motivasi dengan dimensi 1) Need for Achievment (Kebutuhan dalam mencapai kesuksesan), 2) Need for Power (kebutuhan dalam kekuasaan atau otoritas kerja), 3) Need for Affiliation (kebutuhan untuk berafiliasi) dan $\left(\mathrm{X}_{2}\right)$ lingkungan kerja dengan dimensi 1) lingkungan kerja fisik, 2) lingkungan kerja non-fisik. Masalah penelitian yang merupakan dependent variabel atau variabel terikat adalah kinerja karyawan dengan dimensi yang terdiri dari 1) Kejujuran, 2) Kedisiplinan, 3) Loyalitas (Kesetiaan), 4) Kerjasama, dan 5) Perilaku/Sikap.

Adapun yang menjadi objek penelitian atau unit analisis yaitu karyawan PT. Barrix Sinindo Jakarta. Penelitian ini akan dilakukan dalam kurun waktu kurang dari satu tahun yaitu dari bulan Juli 2017 sampai Desember 2017. Dengan metode yang digunakan adalah cross sectional method, seperti yang diungkapkan Creswell (2012) yang menyatakan bahwa Cross sectional method yaitu survei yang dilakukan dengan mengumpulkan data satu persatu dalam satu waktu. Pernyataan lain dikemukakan oleh Husein Umar (2013:45) Pendekatan cross sectional yaitu metode penelitian dengan cara mempelajari objek dalam kurun waktu kurang dari satu tahun,terhitung sejak bulan Juli dengan alat bantu software komputer SPSS 22.0 for Windows..

Penelitian ini dilakukan untuk mengetahui gambaran motivasi, lingkungan kerja dan kinerja karyawan PT. Barrix Sinindo Jakarta.

\section{HASIL PENELITIAN DAN PEMBAHASAN} Gambaran Motivasi

Motivasi adalah cadangan energi potensial, bagaimana energi ini dilepaskan dan dikembangkan tergantung pada kekuatan atau dorongan motivasi individu dan situasi serta peluang yang tersedia (McClelland dalam (Mangkunegara, 2010). Motivasi merupakan hal yang menyebabkan, menyalurkan dan mendukung perilaku manusia. Supaya mau bekerja giat dan antusias mencapai hasil yang memuaskan, motivasi semakin penting karena atasan membagikan pekerjaan kepada bawahannya untuk dikerjakan dengan baik dan teritegrasi kepada tujuan yang diinginkan. Menurut David McClelland yaitu: 1) Need for Achievment (Kebutuhan dalam mencapai kesuksesan), 2) TABEL 1

REKAPITULASI TANGGAPAN KARYAWAN TERHADAP MOTIVASI

\begin{tabular}{|c|l|c|c|c|}
\hline No & \multicolumn{1}{|c|}{ Dimensi } & Skor Total & Skor Ideal & Persentase\% \\
\hline 1 & $\begin{array}{l}\text { Need for Achievment } \\
\text { (Kebutuhan dalam } \\
\text { mencapai kesulsesan) }\end{array}$ & 805 & 1050 & $76,7 \%$ \\
\hline 2 & $\begin{array}{l}\text { Need for Affiliation } \\
\text { (kebutuhan untuk } \\
\text { berafiliasi) }\end{array}$ & 670 & 840 & $79,8 \%$ \\
\hline $\begin{array}{l}\text { Need for Power } \\
\text { (kebutuhan dalam } \\
\text { kekuasaan atau otoritas } \\
\text { kerja) }\end{array}$ & 499 & 630 & $79,2 \%$ \\
\hline \multicolumn{2}{|c|}{ Total Skor } & $\mathbf{1 9 7 4}$ & $\mathbf{2 5 2 0}$ & $\mathbf{7 8 , 3 \%}$ \\
\hline
\end{tabular}

Need for Power (kebutuhan dalam kekuasaan aau otoritas kerja), dan 3) Need for Affiliation (kebutuhan untuk berafiliasi).

Berdasarkan Tabel 1 pada aspek dimensi terdapat skor paling tinggi yaitu pada dimensi Need for Affiliation (kebutuhan untuk berafiliasi) dengan memperoleh skor sebanyak 670 atau $79,8 \%$, sementara dimensi paling rendah yaitu Need for Achievment (Kebutuhan dalam mencapai kesuksesan) dengan memperoleh skor 805 atau $76,7 \%$. Di mana secara keseluruhan dimensi memperoleh skor 1974, apabila dipresentasikan ke dalam skor ideal maka diperoleh presentase sebesar 78,3\%, dapat dikatakan bahwa hampir seluruh responden menyatakan motivasi pada karyawan PT. Barrix Sinindo dalam kategori baik Moch Ali (2013:184).

Skor ideal motivasi adalah 2510 untuk 12 item pertanyaan. Sebagaimana perolehan dari hasil pengolahan data pada variabel motivasi adalah 1974. Sedangkan untuk dapat mencari daerah kontinum yang menunjukkan wilayah ideal dari tanggapan responden terhadap motivasi, berdasarkan rumus Sugiyono (2011:94) adalah sebagai berikut:

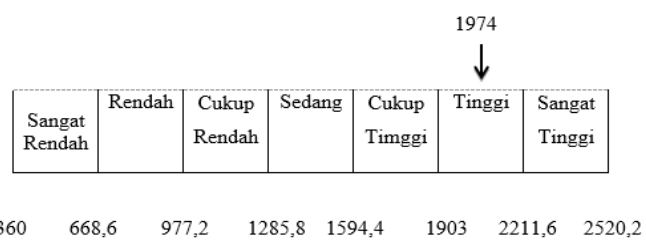

GAMBAR 2

GARIS KONTINUM VARIABEL MOTIVASI

Motivasi adalah cadangan energi potensial, bagaimana energi ini dilepaskan dan dikembangkan tergantung pada kekuatan atau dorongan motivasi individu dan situasi serta peluang yang tersedia (McClelland dalam A.A. Anwar Prabu Mangkunegara, 2010). Motivasi merupakan hal yang menyebabkan, menyalurkan dan mendukung perilaku manusia. Supaya mau bekerja giat dan antusias mencapai hasil yang memuaskan, motivasi semakin penting karena atasan membagikan pekerjaan kepada bawahannya untuk dikerjakan dengan baik dan teritegrasi kepada tujuan yang diinginkan. Menurut David McClelland yaitu: 1) Need for Achievment (Kebutuhan dalam mencapai kesuksesan), 2) Need for Power (kebutuhan dalam kekuasaan aau otoritas kerja), dan 3) Need for Affiliation (kebutuhan untuk berafiliasi).

Berdasarkan hasil penelitian dari angket yang disebar kepada 30 responden dapat diketahui bahwa motivasi pada karyawan PT. Barrix Sinindo mencapai skor 1974s dari skor kriterium atau jumlah maksimal perolehan nilai responden terletak pada daerah efektif yaitu pada 
interval 1903-2211,3 sehingga dapat dikatakan bahwa dalam penelitian ini motivasi yang dimiliki oleh karyawan PT. Barrix Sinindo telah diaplikasikan dengan efektif, namun motivasi tersebut perlu ditingkatkan lagi, karena semua dimensi berada di bawah skor ideal.Sebagaimana motivasi kerja merupakan salah satu faktor penting dalam keberlangsungan organisasi. Motivasi kerja merupakan factor penting dalam mencapai kinerja yang tinggi dari seorang pegawai. Dalam hal ini motivasi kerja merupakan pemberian semangat dan dorongan kerja kepada seorang karyawan di dalam bekerja. karyawan selalu membutuhkan motivasi yang lebih dari organisasi, pemimpin dan rekan kerja, hal ini karena jika motivasi kerja tinggi pada seorang pegawai maka pegawai akan melakukan hal yang lebih baik dari kinerja sebelumnya. Dengan demikian organisasi di rasa perlu untuk memahami dan memperbaiki motivasi kerja kepada karyawan guna terciptanya kinerja yang baik dalam organisasi.

\section{Gambaran Lingkungan Kerja}

$$
\text { Menurut Sedarmayanti }
$$

Lingkungan kerja adalah keseluruhan alat perkakas,,lingkungan di mana seseorang bekerja, metode kerja,,serta pengaturan kerja. Suatu perusahaan tidak dapat dilepaskan dari lingkungan sekitarnya yang mempunyai pengaruh langsung terhadap para karyawan. Lingkungan kerja meliputi segala sesuatu yang mengelilingi

TABEL 2

REKAPITULASI TANGGAPAN KARYAWAN TERHADAP LINGKUNGAN KERJA

\begin{tabular}{|c|l|c|c|c|}
\hline No & \multicolumn{1}{|c|}{ Dimensi } & Skor Total & Skor Ideal & Persentase\% \\
\hline 1 & Lingkungan Kerja Fisik & 1961 & 2520 & $79 \%$ \\
\hline 2 & $\begin{array}{l}\text { Lingkungan Kerja Non- } \\
\text { Fisik }\end{array}$ & 982 & 1260 & $78 \%$ \\
\hline \multicolumn{2}{|c|}{ Total Skor } & $\mathbf{2 9 4 3}$ & $\mathbf{3 7 8 0}$ & $\mathbf{7 7 , 9 \%}$ \\
\hline
\end{tabular}

Sumber: Hasil Pengolahan Data 2018

pekerjaan, berbagai tugas dan tingkat otonomi, tuntutan pekerjaan, dan persyaratan untuk mengekspresikan emosi tenaga kerja. Kondisi lingkungan dikatakan baik apabila manusia dapat melaksanakan kegiatan secara optimal, sehat, aman, dan nyaman. Menurut Sedarmayanti (2015:13) menyatakan bahwa terbentuknya suatu kondisi kerja yang dapat menunjang kemampuan karyawan dibagi 2, yaitu: lingkungan kerja fisik dan lingkungan kerja non-fisik.

Berdasarkan Tabel 2 pada aspek dimensi terdapat skor paling tinggi yaitu pada dimensi Lingkungan Kerja Fisik dengan memperoleh skor sebanyak 1961 atau 79\%, sementara dimensi paling rendah yaitu Lingkungan Kerja Non-Fisik dengan memperoleh skor 982 atau 78\%. Di mana secara keseluruhan dimensi motivasi memperoleh skor 2943, apabila dipresentasikan ke dalam skor ideal maka diperoleh presentase sebesar 77,9\%, dapat dikatakan bahwa hampir seluruh responden menyatakan lingkungan kerja pada karyawan PT.

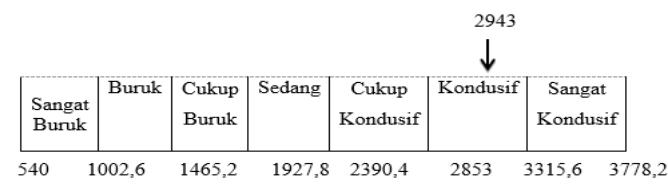

Barrix Sinindo dalam kategori baik Moch Ali (2013:184).

Skor ideal lingkungan kerja adalah 3780 untuk 18 item pertanyaan. Sebagaimana perolehan dari hasil pengolahan data pada variabel motivasi adalah 2943. Sedangkan untuk dapat mencari daerah kontinum yang menunjukkan wilayah ideal dari tanggapan responden terhadap motivasi, berdasarkan rumus Sugiyono (2011:94) adalah sebagai berikut:

GAMBAR 3

GARIS KONTINUM VARIABEL LINGKUNGAN KERJA

Secara ideal skor yang diharapkan untuk jawaban karyawan terhadap pertanyaan nomor 1 sampai dengan 18 adalah 2943. Dari perhitungan diatas menunjukkan nilai yang diperoleh adalah sebesar 2943 dari skor ideal yaitu 3780, dengan demikian lingkungan kerja berada pada kategori tinggi. Dengan demikian dapat dikatakan bahwa sebagian besar karyawan menilai bahwa lingkungan kerja yang tinggi, akan tetapi lingkungan kerja masih perlu ditingkatkan karena semua dimensi berada dibawah skor ideal.

Lingkungan kerja dikatakan kondusif jika lingkungannya selalu bersih, rapi dan masing-masing karyawan memiliki konsistensi dan disiplin dalam bekerja sehingga mampu mendukung terciptanya tingkat efisiensi dan produktivitas yang tinggi di perusahaan. Lingkungan kerja menunjuk pada hal-hal yang berada di sekeliling dan melingkupi kerja karyawan. Kondisi ini lebih banyak tergantung pimpinan, sehingga suasana kerja yang tercipta tergantung pada pola yang diciptakan pimpinan.

Menurut Sedarmayanti (2015:13) Lingkungan kerja adalah keseluruhan alat perkakas, ,lingkungan di mana seseorang bekerja, metode kerja,,serta pengaturan kerja. Suatu perusahaan tidak dapat dilepaskan dari lingkungan sekitarnya yang mempunyai pengaruh langsung terhadap para karyawan. Lingkungan kerja meliputi segala sesuatu yang mengelilingi pekerjaan, berbagai tugas dan tingkat otonomi, tuntutan pekerjaan, dan persyaratan untuk mengekspresikan emosi tenaga kerja. Kondisi lingkungan dikatakan baik apabila manusia dapat melaksanakan kegiatan secara optimal, sehat, aman, dan nyaman. Menurut Sedarmayanti (2015:13) menyatakan bahwa terbentuknya suatu 
kondisi kerja yang dapat menunjang kemampuan karyawan dibagi 2, yaitu: lingkungan kerja fisik dan lingkungan kerja non-fisik.

\section{Gambaran Kinerja Karyawan}

$$
\text { Menurut (Gomez-Mejia et al., }
$$

2012)kinerja merupakan perilaku nyata yang ditampilkan setiap orang sebagai prestasi kerja yang dihasilkan oleh karyawan sesuai dengan perannya dalam perusahaan. Mengelola kinerja adalah tentang mengembangkan kemampuan organisasi, kapasitas organisasi untuk melakukan secara efektif dalam mencapai hasil yang diinginkan. Mengelola kinerja melibatkan

TABEL 3

REKAPITULASI TANGGAPAN KARYAWAN TERHADAP KINERJA
\begin{tabular}{|c|l|c|c|c|}
\hline No & \multicolumn{1}{|c|}{ Dimensi } & Skor Total & Skor Ideal & Persentase\% \\
\hline 1 & Kejujuran & 326 & 420 & $78 \%$ \\
\hline 2 & Kedisiplinan & 334 & 420 & $80 \%$ \\
\hline 3 & Loyalitas (Kesetiaan) & 507 & 630 & $80 \%$ \\
\hline 4 & Kerjasama & 668 & 840 & $80 \%$ \\
\hline 5 & Perilaku/Sikap & 309 & 420 & $74 \%$ \\
\hline & Total Skor & $\mathbf{2 1 4 4}$ & $\mathbf{2 7 3 0}$ & $\mathbf{7 8 , 5 \%}$ \\
\hline
\end{tabular}

Sumber: Hasil Pengolahan Data 2018

mengambil tindakan sistematis untuk meningkatkan kinerja organisasi, tim dan individu. PT. Barriq Sinindo (2017) mengemukakan bahwa dimensi kinerja terdiri dari: 1) Kejujuran, 2) Kedisiplinan, 3) Loyalitas (Kesetiaan), 4) Kerjasama, dan 5) Perilaku/Sikap.

Berdasarkan Tabel 3 pada aspek dimensi terdapat skor paling tinggi yaitu pada dimensi kedisiplinan dan loyalitas yang masing-masing sebesar $80 \%$, kedisiplinan dengan total 334,

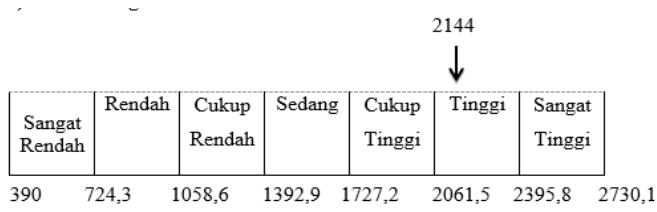

loyalitas total skor 507 dan kerjasama dengan skor 668. Sementara dimensi paling rendah yaitu perilaku/sikap dengan memperoleh skor 309 atau $74 \%$. Di mana secara keseluruhan dimensi kinerja memperoleh skor 2144, apabila dipresentasikan ke dalam skor ideal maka diperoleh presentase sebesar 78,5\%, dapat dikatakan bahwa hampir seluruh responden menyatakan kinerja karyawan PT. Barrix Sinindo dalam kategori baik Moch Ali (2013:184).

\section{GAMBAR 4}

\section{GARIS KONTINUM VARIABEL KINERJA}

Secara ideal skor yang diharapkan untuk jawaban karyawan terhadap pertanyaan nomor 1 sampai dengan 13 adalah 2730. Dari perhitungan diatas menunjukkan nilai yang diperoleh adalah sebesar 2144 dari skor ideal yaitu 2730, dengan demikian kinerja karyawan berada pada kategori tinggi. Dengan demikian dapat dikatakan bahwa sebagian besar karyawan menilai bahwa kinerja karyawan yang tinggi, akan tetapi kinerja karyawan masih perlu ditingkatkan karena semua dimensi berada dibawah skor ideal.

Menurut Gomez-Mejia David B. Balkin and Robert L.Cardy (2012) kinerja merupakan perilaku nyata yang ditampilkan setiap orang sebagai prestasi kerja yang dihasilkan oleh karyawan sesuai dengan perannya dalam perusahaan. Mengelola kinerja adalah tentang mengembangkan kemampuan organisasi, kapasitas organisasi untuk melakukan secara efektif dalam mencapai hasil yang diinginkan. Mengelola kinerja melibatkan mengambil tindakan sistematis untuk meningkatkan kinerja organisasi, tim dan individu. PT. Barriq Sinindo (2017) mengemukakan bahwa dimensi kinerja terdiri dari: 1) Kejujuran, 2) Kedisiplinan, 3) Loyalitas (Kesetiaan), 4) Kerjasama, dan 5) Perilaku/Sikap.

\section{Pengaruh Motivasi dan Lingkungan Kerja terhadap Kinerja Pegawai}

Berdasarkan hasil penelitian yang bersifat empiris berupa pengaruh motivasi dan lingkungan kerja terhadap kinerja pegawai. Kinerja pegawai dipengaruhi motivasi dan lingkungan kerja. Besarnya pengaruh secara langsung motivasi dan lingkungan kerja terhadap kinerja pegawai karyawan sebesar 49,4\%. Sehingga dapat disimpulkan bahwa motivasi dan lingkungan kerja memiliki pengaruh terhadap kinerja pegawai.

Motivasi merupakan hal yang menyebabkan, menyalurkan dan mendukung perilaku manusia. Supaya mau bekerja giat dan antusias mencapai hasil yang memuaskan, motivasi semakin penting karena atasan membagikan pekerjaan kepada bawahannya untuk dikerjakan dengan baik dan teritegrasi kepada tujuan yang diinginkan. Manusia memiliki motivasi yang berbeda tergantung dari banyak faktor seperti kepribadian dan ambisi. Seseorang yang termotivasi menunjukan usaha dan bekerja keras Robbins \& Coulter (2010). Motivasi adalah cadangan energi potensial, bagaimana energi ini dilepaskan dan dikembangkan tergantung pada kekuatan atau dorongan motivasi individu dan situasi serta peluang yang tersedia (McClelland dalam A.A. Anwar Prabu Mangkunegara, 2010)

$$
\text { Kepemimpinan Transformasional }
$$
sebagai pendekatan kepemimpinan yang menciptakan perubahan positif dan bernilai bagi suatu organisasi Lensufiie (2010:81). Gaya kepemimpinan transformasional merupakan sebuah proses dimana gaya dari pemimpin dan pengikut akan saling memotivasi spirit dalam organisasi. Kepemimpinan transformasional memiliki pengertian kepemimpinan yang bertujuan untuk perubahan, perubahan yang dimaksud diasumsikan sebagai perubahan yang 
lebih baik menentang status quo dan aktif, B. A. Setiawan \& Muhith, (2013).

motivasi kerja. Motivasi merupakan faktor yang sangat menentukan kinerja Ricky W Griffin, (2003). Menurut Brantas, (2009:101) bahwa motivasi ini merupakan subjek yang penting bagi manajer, karena menurut definisi manajer harus bekerja dengan melalui orang lain. Manajer perlu memahami orang-orang berperilaku tertentu agar dapat mempengaruhi untuk bekerja sesuai dengan yang diinginkan organisasi. Motivasi sebagai suatu keahlian dalam mengarahkan karyawan agar mau bekerja secara berhasil, sehingga mencapai keinginan para karyawan untuk meningkatkan kinerja sekaligus tercapainya tujuan organisasi. Motivasi terbentuk dari sikap pegawai dalam menghadapi situasi kerja di perusahaan. Motivasi merupakan kondisi atau energi yang menggerakkan diri pegawai yang terarah untuk mencapai tujuan perusahaan. Sikap mental pegawai yang positif terhadap situasi kerja itulah yang memperkuat motivasi kerjanya untuk dapat mencapai kinerja semaksimal mungkin Rumpak (2016).

Motivasi adalah keinginan dalam diri seseorang yang menyebabkan orang tersebut bertindak. Orang bertindak karena satu alasan yaitu untuk mencapai tujuan. Jadi, motivasi adalah sebuah dorongan yang diatur oleh tujuan dan jarang muncul dalam kekosongan Mathis \& Jackson (2009). Menurut Newstrom (2011:109) yang menyatakan bahwa, motivasi adalah hasil dari kumpulan kekuatan internal dan eksternal yang mmenyebabkan pekerja memilih jalan bertindak yang sesuai dan menggunakan perilaku tertentu. Idealnya perilaku ini akan diarahkan pada pencapaian tujuan organisasi.

Motivasi adalah kesediaan untuk mengeluarkan tingkat upaya yang tinggi untuk tujuan organisasi yang di kondisikan oleh kemampuan upaya itu dalam memenuhi beberapa kebutuhan individual. Kebutuhan terjadi apabila tidak ada keseimbangan antara apa yang di miliki dan apa yang di harapkan, dorongan merupakan kekuatan mental yang berorientasi pada pemenuhan harapan dan pencapaian tujuan dan tujuan adalah sasaran atau hal yang ingin dicapai oleh seseorang/individu Menurut Robbins and Judge, (2007:51). Selanjutnya George et al., (2012:157) yang berpendapat bahwa: "Work motivation can be defined as the psychological forces within a person that determine the direction of that person's behavior in an organization". Motivasi kerja dapat didefinisikan sebagai kekuatan psikologis dalam diri seseorang yang menentukan arah perilaku orang itu dalam sebuah organisasi.

$$
\text { Selain gaya kepemimpinan }
$$
transformasional, faktor lain yang mempengaruhi kinerja pegawai adalah lingkungan kerja. Alex S. Nitisemito (2010:183) menyatakan bahwalingkungan kerja adalah segala sesuatu yang ada disekitar para pekerja dan yang dapat mempengaruhi dirinya dalam menjalankan tugastugas yang dibebankan.. Dalam penelitian ini indikator yang digunakan untuk mengukur lingkungan kerja adalah, lingkungan kerja fis menyatakan bahwa lingkungan kerja melibatkan semua aspek yang bertindak dan bereaksi pada tubuh dan pikiran seorang karyawan. Lingkungan kerja menurut adalah keseluruhan alat perkakas, lingkungan di mana seseorang bekerja, metode kerja,,serta pengaturan kerja. Menurut Lingkungan kerja adalah keseluruhan alat perkakas dan bahan yang dihadapi, lingkungan sekitarnya di mana seseorang bekerja, metode kerjanya, serta pengaturan kerjanya baik sebagai perseorangan maupun sebagai kelompok. menyatakan bahwa lingkungan kerja adalah segala sesuatu yang ada disekitar para pekerja dan yang dapat mempengaruhi dirinya dalam menjalankan tugas-tugas yang dibebankan. Menurut Mardiana (2010:57) lingkungan kerja adalah lingkungan dimana pegawai melakukan pekerjaannya sehari-hari. Sutermeister (1976) dalam Syamsul Hadi Senen (2009:31) menyatakan bahwa lingkungan kerja fisik merupakan suatu keadaan yang berkaitan dengan tempat kerja secara nyata dapat diamati dan dirasakan, yaitu masalah kebisingan, pencahayaan, ventilasi, suhu, keamanan, waktu istirahat, kelembapan dan musik yang berhubungan erat dengan karakteristik pekerjaan.

Lingkungan kerja yang kondusif memberikan rasa aman dan memungkinkan para pegawai untuk dapat berkerja optimal. Lingkungan kerja dapat mempengaruhi emosi pegawai. Jika pegawai menyenangi lingkungan kerja dimana dia bekerja, maka pegawai tersebut akan betah di tempat kerjanya untuk melakukan aktivitas sehingga waktu kerja dipergunakan secara efektif dan optimis prestasi kerja pegawai juga tinggi. Lingkungan kerja tersebut mencakup hubungan kerja yang terbentuk antara sesama pegawai dan hubungan kerja antar bawahan dan atasan serta lingkungan fisik tempat pegawai bekerja.

Masalah lingkungan kerja dalam suatu organisasi sangatlah penting, dalam hal ini diperlukan adanya pengaturan maupun penataan faktor-faktor lingkungan kerja dalam penyelenggaraan aktivitas organisasi. Sesuai dengan Keputusan Menteri Kesehatan No. 261/MENKES/SK/II/1998 Tentang: Persyaratan Kesehatan Lingkungan Kerja bahwa lingkungan kerja perkantoran meliputi semua ruangan, halaman dan area sekelilingnya yang merupakan bagian atau yang berhubungan dengan tempat 
kerja untuk kegiatan perkantoran. Persyaratan kesehatan lingkungan kerja dalam keputusan ini diberlakukan baik terhadap kantor yang berdiri sendiri maupun yang berkelompok. Setiap perusahaan pasti mengharapkan suatu lingkungan kerja yang selalu bersih, rapi, dan masing-masing orang mempunyai konsistensi dan disiplin diri, sehingga mampu mendukung terciptanya tingkat efisiensi dan produktivitas yang tinggi di perusahaan. Lingkungan kerja menunjuk pada hal-hal yang berada di sekeliling dan melingkupi kerja karyawan. Kondisi ini lebih banyak tergantung pimpinan, sehingga suasana kerja yang tercipta tergantung pada pola yang diciptakan pimpinan.

Berdasarkan uraian tersebut, apabila motivasi dan lingkungan kerja diterapkan dengan baik maka akan diperoleh hasil output kerja yang optimal, sehingga kinerja karyawan pun dapat meningkat dan pada akhirnya dapat mencapai tujuan-tujuan organisasi secara keseluruhan.

\section{KESIMPULAN DAN REKOMENDASI Kesimpulan}

Berdasarkan pembahasan teori, hasil penelitian, dan pengujian analisis regresi linier berganda yang dilakukan mengenai pengaruh motivasi dan lingkungan kerja terhadap kinerja karyawan PT. Barrix Sinindo Jakarta dapat disimpulkan sebagai berikut:

1. Gambaran mengenai motivasi karyawan PT. Barrix Sinindo Jakarta tinggi. Hal ini dapat dilihat dari dimensi-dimensi motivasi yang terdiri dari need for achievment (kebutuhan dalam mencapai kesuksesan), need for power (kebutuhan dalam kekuasaan aau otoritas kerja), dan need for affiliation (kebutuhan untuk berafiliasi). Dimensi need for affiliation (kebutuhan untuk berafiliasi) merupakan dimensi yang memiliki penilaian yang paling tinggi dalam motivasi, sementara dimensi yang memperoleh skor terendah terdapat pada dimensi need for achievment (Kebutuhan dalam mencapai kesuksesan).

2. Gambaran mengenai lingkungan kerja PT. Barrix Sinindo Jakarta tinggi. Hal ini dapat dilihat dari dimensi-dimensi lingkungan kerja yang terdiri dari lingkungan kerja fisik dan lingkungan kerja non-fisik.
Dimensi lingkungan kerja fisik merupakan dimensi yang memiliki penilaian yang paling tinggi dalam lingkungan kerja, sementara dimensi yang memperoleh skor terendah terdapat pada dimensi lingkungan kerja non-fisik.

3. Gambaran mengenai kinerja karyawan PT. Barrix Sinindo Jakarta tinggi. Hal ini dapat dilihat dari dimensi-dimensi komitmen organisasi yang terdiri dari kejujuran, kedisiplinan, loyalitas (kesetiaan), kerjasama, dan perilaku/sikap. Dimensi kedisiplinan, loyalitas dan kerjasama merupakan dimensi yang memiliki penilaian yang paling tinggi, sementara dimensi yang memperoleh skor terendah terdapat pada dimensi perilaku/sikap.

\section{Rekomendasi}

Berdasarkan hasil penelitian, maka penulis menyarankan beberapa hal mengenai motivasi dan lingkungan kerja yang dapat meningkatkan kinerja karyawan, yaitu sebagai berikut:

1. Motivasi karyawan PT. Barrix Sinindo Jakarta dapat ditingkatkan pada aspek Need for Achievment (Kebutuhan dalam mencapai kesuksesan) dengan memperbaiki dan meningkatkan motivasi yang telah ada, sehingga dapat menjadi sarana bagi karyawan untuk mampu merasakan dan memahami apa yang dirasakan karyawan lain melalui persahabatan, mencari persetujuan atau kesepakatan dari orang lain, lebih suka bekerja sama daripada berkompetisi dan selalu berusaha menghindari konflik sehingga motivasi karyawan dapat terbangun dengan baik.

2. Lingkungan kerja karyawan PT. Barrix Sinindo dapat ditingkatkan pada aspek mengenali lingkungan kerja non-fisik. Keadaan yang terjadi berkaitan dengan hubungan kerja, baik hubungan atasan dengan 
karyawan ataupun hubungan sesama rekan kerja perlu dibangun dengan baik, agar karyawan dapat merasakan lingkungan kerja yang positif dan kondusif sehingga dapat tercipta lingkungan kerja yang baik dalam perusahaan.

3. Kinerja karyawan PT. Barrix Sinindo Jakarta dapat ditingkatkan pada aspek perilaku/sikap. Perilaku/sikap ini merupakan bentuk interaksi antara karateristik individu dengan karakteristik organisasi. perilaku/sikap ini penting untuk membangun motivasi, emosional, perseptual dan kognitif. Perilaku/sikap ini perlu dibentuk dalam diri masing-masing individu agar membawa pengaruh positif bagi suatu organisasi dalam hal ini perusahaan.

\section{DAFTAR PUSTAKA}

Ali, M. (2013). Penelitian Kependidikan Prosedur dan Strategi. Bandung: CV Angkasa.

Amstrong, M. (2010). Armstrong's handbook of Human Resorce Managem ent Practice 11th edition, 2010.

Gomez-Mejia, R, L., \& Balkin, D. B. (2012). Management. New Jersey: Pearson Education.

Mangkunegara, A. A. A. P. (2010). Manajemen Sumber Daya Manusia Perusahaan. Bandung: PT. Remaja Rosda Karya.

Masharyono, \& Sumiyati. (2016). Physical Work Environment Effect on Employee Productivity of Textile Industry. Advances in Economics, Business and Management Research, 15, 630-632.

Purnama, R. (2008). Pengaruh Motivasi Kerja Terhadap Produktivitas Kerja Karyawan Pada Bagian Produlsi CV . Epsilon Bandung, 7, 58-72.

Rivai, V., \& Jauvani, E. (2009). Manajemen Sumber Daya Manusia Untuk Perusahaan Dari Teori ke Praktik (2nd ed.). Jakarta: PT Raja Grafindo Persada.

Robbins, S. P., \& Coulter, M. (2010). Manajemen (10th ed.). Jakarta: Erlangga.

Robbins, S. P., \& Coulter, M. (2012). Management. New Jersey: Pearson Education, Inc.

Robbins and Judge. (2013). Human Resource
Management . New Jersey: Pearson Education inc, Publishing as Prentice Hall, 2013.

Senen, Hadi Syamsul dan Solihat, S. (2008). Pengaruh Motivasi Kerja Dan kemampuan Kerja Karyawan Terhadap Produktivitas Kerja Karyawan Pada PT.Safilindo Permata, 7, 1-15.

Senen, S. H. (2009). Pengaruh Kondisi Sosial, Kondisi Fisik, Kebutuhan Individu dan Kemampuan kerja Terhadap Kinerja Pelayanan serta Implikasinya Terhadap Kepuasan kerja Pegawai (Studi terhadap Pegawai PT. Telekomunikasi Indonesia, Tbk di Kantor Daerah Telekomunikasi (Kandate. 
Journal of Business Management Education | Volume 3, Number 2, September 2018, page. 1-11

\section{Curriculum Vitae}

My Name is Muhammad Putra Aviantara. Born at $30^{\text {st }}$ June 1994 in Bandung City. Now, i live in Blok BB 23 No 7 Bekasi. Previous education in TK Islamic Darul Falah, Darussalam Elementary School, Al-Azhar High School Kemang Pratama, $P B$. Soedriman Senior High School Lembang, and now student of Business Management Education in UPI. Active in organization of student associations IM2B. My Interpersonal Skill are hard worker, adaptable, good attitude, kind, communicative, diligent, tolerant, discipline, honest, responsible, able to work in a team and in individual. 